\title{
PEMANFAATAN BIJI KELOR SEBAGAI KOAGULAN PADA PROSES KOAGULASI LIMBAH CAIR INDUSTRI TAHU DENGAN MENGGUNAKAN JAR TEST
}

\author{
Riko Putra*, Buyung Lebu, MHD Darwis Munthe, Ahmad Mulia Rambe \\ Departemen Teknik Kimia, Fakultas Teknik, Universitas Sumatera Utara, \\ Jalan Almamater Kampus USU, Medan 20155 Indonesia \\ *E-Mail: driechost@yahoo.com
}

\begin{abstract}
Abstrak
Pemanfaatan biji kelor yang selama ini hanya sebagai limbah yang jarang digunakan, perlu dikembangkan lebih lanjut untuk pengolahan limbah cair yang lebih ekonomis dan ramah lingkungan. Penelitian ini dilakukan untuk mengetahui pengaruh biji kelor sebagai koagulan dan waktu pengendapan terhadap persentase penurunan turbiditas, TSS dan COD limbah cair industri tahu dengan menggunakan metode koagulasi dan flokulasi. Variabel penelitian adalah dosis serbuk biji kelor (2000, 3000, 4000, 5000 dan $6000 \mathrm{mg} / \mathrm{liter})$ limbah cair industri tahu, waktu pengendapan (50, 60 dan 70 menit) dengan ukuran partikel 50 mesh dan $\mathrm{pH}$ yang digunakan adalah pH limbah cair industri tahu. Penelitian ini menggunakan peralatan jar test dan analisa dilakukan secara grafis. Hasil penelitian menunjukkan bahwa pada rentang pengamatan yang dilakukan, dosis biji kelor sebagai koagulan yang optimum adalah $3000 \mathrm{mg} / \mathrm{liter}$ limbah cair industri tahu, dimana waktu pengendapan 50 menit mampu menyisihkan turbiditas sebesar 89,42\%, TSS sebesar 98,73\% dan COD sebesar $69,58 \%$.
\end{abstract}

Kata kunci : biji kelor, limbah cair industri tahu, koagulasi, flokulasi

\begin{abstract}
For a long time the use of moringa seed as waste rarely used, needs developing further to process liquid waste more economically and environmentally friendly. The research was done to find the effect of moringa seed as coagulant and the precipitation time to the turbidity decrease percentage, TSS and COD of liquid waste of whey industry by using the coagulation-flocculation method. The research variables are moringga seed dose (2000, 3000, 4000, 5000 and $6000 \mathrm{mg} / \mathrm{liter}$ of liquid waste of whey industry), the precipitation time (50, 60 and 70 minutes) with the particle size of 50 mesh and $\mathrm{pH}$ used is $\mathrm{pH}$ of liquid waste of whey industry. The research used the jar test tool. The data analysis was done graphically. The result of the research showed that in the range of time the observation was done, the moringa seed dose as an optimal coagulant being $3000 \mathrm{mg} / \mathrm{liter}$ of the liquid waste of whey industry in the precipitation time of 50 minutes could set aside the turbidity over $89,42 \%$, TTS over $98,73 \%$ and COD over $69,58 \%$.
\end{abstract}

Keywords: moringa seeds, liquid waste industrial of whey, coagulation, flocculation

\section{Pendahuluan}

Biji kelor dapat dipergunakan sebagai salah satu koagulan alami alternatif yang tersedia secara lokal. Biji kelor yang dipergunakan adalah yang matang atau tua yang memiliki kadar air kurang dari $10 \%$ [3].

Biji kelor yang selama ini kurang termanfaaatkan, bisa digunakan untuk pengolahan limbah cair yang lebih ekonomis dan ramah lingkungan [6].

Penelitian ini dilakukan untuk mengetahui pengaruh biji kelor sebagai koagulan serta waktu pengendapan terhadap persentase penurunan Turbiditas, TSS dan COD limbah cair industri tahu dengan menggunakan metode koagulasi dan flokulasi [10].

\section{Teori}

Sejak awal tahun 1980-an oleh Jurusan Teknik Lingkungan ITB, biji kelor digunakan untuk penjernihan air permukaan (air kolam, air sungai, air danau sampai ke air sungai) sebagai pengendap (koagulan) dengan hasil yang memuaskan. Oleh karena itu rangkaian penelitian terhadap manfaat tanaman kelor mulai dari daun, kulit batang, buah sampai bijinya, sejak awal tahun 1980-an telah dimulai [1].

Koagulasi adalah proses pengolahan air/limbah cair dengan cara menstabilasi partikel - partikel koloid untuk memfasilitasi pertumbuhan partikel selama flokulasi, sedangkan flokulasi itu adalah proses pengolahan air dengan cara mengadakan kontak diantara partikel - partikel koloid yang telah mengalami destabilisasi sehingga ukuran partikel - partikel tersebut bertambah menjadi partikel - partikel yang lebih besar [7].

Menurut penelitian dilaporkan bahwa tepung biji kelor adalah bahan alami yang 
dapat membersihkan limbah cair relatif sama efektifnya bila dilakukan dengan cara pembersihan menggunakan bahan kimia. Tepung biji kelor mampu mereduksi bakteri secara luar biasa yaitu sebanyak 90-99,9\% yang melekat pada partikel-partikel padat, sekaligus menjernihkan air yang relatif aman serta dapat digunakan sebagai air minum [8].

\section{Metodologi Penelitian}

Bahan baku dalam percobaan ini adalah limbah cair industri tahu yang dihasilkan dari proses penggumpalan pada proses pembuatan tahu. Limbah cair yang diambil adalah limbah cair tahu berat dari indutri tahu di kota Medan, kemudian dibawa ke laboratorium.

Bahan koagulan yang digunakan dalam percobaan ini adalah serbuk biji kelor. Untuk membuat koagulan serbuk biji kelor, digunakan buah kelor yang sudah tua dan kering secara alami di pohonnya lalu diambil bijinya dan dipisahkan dari daging buahnya.

Biji dengan cangkangnya tersebut dibersihkan lalu di blender hingga menjadi serbuk dan diayak dengan ukuran partikel 50 mesh lalu dikeringkan dalam oven panas pada suhu $105{ }^{\circ} \mathrm{C}$ selama 30 menit untuk menghomogenkan dan menurunkan kadar airnya hingga konstan kurang $10 \%$. Serbuk biji kelor selanjutnya sudah siap digunakan sebagai koagulan.

Prosedur penelitian untuk mengetahui pengaruh dosis koagulan serbuk biji kelor terhadap Turbiditas, TSS dan COD limbah cair industri tahu pada proses koagulsi/ flokulasi pada peralatan Jar Test adalah sebagai berikut :

1. Dimasukkan limbah cair industri tahu ke dalam wadah, Diukur pH, Turbiditas, TSS, dan COD awal limbah cair industri tahu.

2. Beaker diisi dengan sampel limbah cair industri tahu sebanyak 200 ml,Kemudian koagulan ditambahkan ke dalam beaker sebanyak masing-masing 2000, 3000, 4000, 5000, dan $6000 \mathrm{mg} / 200 \mathrm{ml}$ limbah cair industri tahu.

3. Sampel kemudian diaduk cepat selama 3 menit (100 rpm) dan diikuti dengan pengadukan lambat selama 12 menit (40 rpm), Setelah pengadukan diendapkan selama 50, 60 dan 70 menit.

4. Setelah pengendapan hasil diambil dan dilakukan pengukuran $\mathrm{pH}$, Turbiditas, TSS, dan COD sampel dan diambil waktu optimumnya.

\section{Hasil dan Pembahasan}

Pengaruh dosis koagulan serbuk biji kelor terhadap penyisihan turbiditas limbah cair industri tahu untuk beberapa waktu pengendapan dan dosis koagulan.

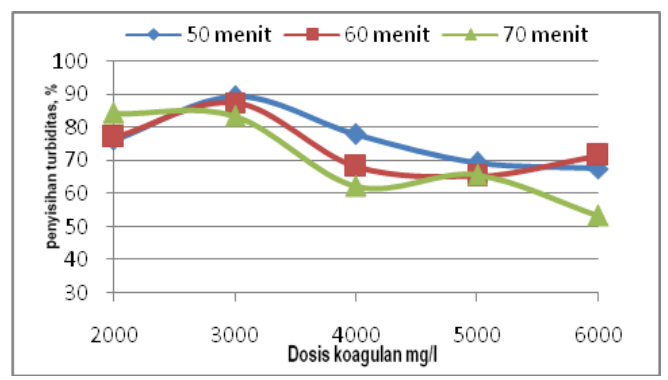

Gambar 1. Pengaruh dosis koagulan serbuk biji kelor terhadap penyisihan turbiditas limbah cair industri tahu

Pada gambar 1 dapat dilihat bahwa serbuk biji kelor mampu menurunkan turbiditas limbah cair industri tahu pada berbagai waktu pengendapan dan dosis koagulan. Penyisihan turbiditas optimum diperoleh pada dosis koagulan serbuk biji kelor $3000 \mathrm{mg} / \mathrm{L}$ limbah cair industri tahu pada waktu pengendapan 50 menit sebesar $89,42 \%$, dengan ukuran partikel 50 mesh dan $\mathrm{pH} 4$ limbah cair industri tahu. Pada penelitian terdahulu menggunakan serbuk biji kelor untuk menyisihkan 87,88 \% turbiditas dari limbah cair industri tahu dengan ukuran partikel 140 mesh, waktu pengendapan 60 menit, $\mathrm{pH} 4$ limbah cair industri tahu dengan dosis koagulan partikel biji asam jawa $3000 \mathrm{mg} / \mathrm{L}$ [4].

Dari hasil yang diperoleh jika dibandingkan dengan penelitian terdahulu yang telah dilakukan dengan menggunakan biofilter aerobic dengan media batu kerikil sebagai biofilter untuk mengolah limbah cair industry tahu dengan variasi kombinasi $500 \mathrm{mg} / \mathrm{L}$, waktu 9 jam memberikan persen reduksi COD sebesar $(72,93 \%)$ dan persen reduksi MLSS sebesar $(74,96 \%)$ [9]. Untuk mendapatkan hasil maksimal dengan koagulan biji asam jawa limbah cair industri tahu, dosis koagulan yang dibutuhkan sebesar $3000 \mathrm{mg} / \mathrm{L}$ [5], sedangkan pada biji kelor limbah cair industri tahu dibutuhkan dosis koagulan sebesar 3000 mg/L dan penyisihan lebih besar di dapatkan dengan memakai koagulan biji kelor yaitu sebesar89,42\%.

Dosis koagulan sangat berpengaruh terhadap penyisihan turbiditas limbah cair industri tahu Karena dengan memberikan dosis yang tepat maka penyisihan turbiditas sampel akan semakin signifikan. Suatu koagulan dikatakan efektif, apabila mampu mengurangi nilai turbiditas sebesar $50 \%$ sehingga koagulan partikel biji kelor ini merupakan koagulan yang 
efektif untuk menurunkan turbiditas limbah cair industri tahu [10].

Pengaruh dosis koagulan serbuk biji kelor terhadap penyisihan TSS limbah cair industri tahu untuk beberapa waktu pengendapan dan dosis koagulan.

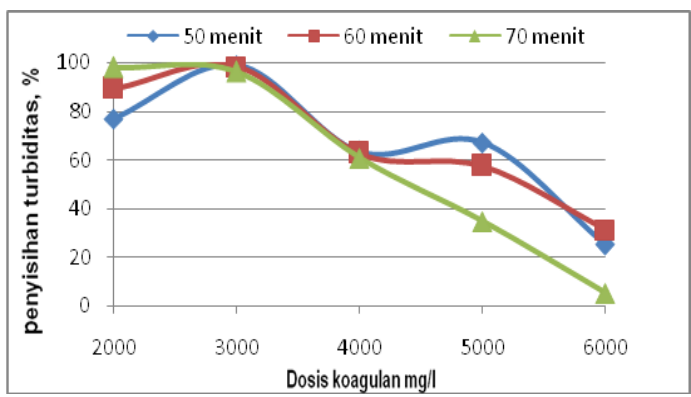

Gambar 2. Pengaruh dosis koagulan serbuk biji kelor terhadap penyisihan TSS limbah cair industri tahu

Pada gambar 2 dapat dilihat bahwa penyisihan TSS tertinggi diperoleh pada dosis koagulan serbuk biji kelor $3000 \mathrm{mg} / \mathrm{L}$ limbah cair industri tahu dengan waktu pengendapan 50 menit dengan penyisihan sebesar 98,78\% Pada penelitian terdahulu menggunakan biji asam jawa, untuk menyisihkan 98,78 \% TSS dari limbah cair industri tahu dengan ukuran partikel 140 mesh, waktu pengendapan 60 menit, pH 4 limbah cair industri tahu dengan dosis koagulan partikel biji kelor $3000 \mathrm{mg} / \mathrm{L}$ [5].

Dapat kita lihat dengan konsentrasi yang sama tetapi dengan waktu pengendapan dan mesh yang berbeda mendapatkan hasil yang sama besar 98,78 \%, hal ini menunjukkan bahwa TSS yang berada pada limbah cair industri tahu hampir seluruhnya dapat diendapkan dan juga penggunaan koagulan biji kelor lebih baik dan efektif.

\section{Pengaruh dosis koagulan serbuk biji kelor terhadap penyisihan COD lombah cair industry tahu}

Analisa penyisihan COD limbah cair industri tahu hanya dilakukan terhadap tingkat turbiditas terendah dari koagulan serbuk biji kelor dibandingkan dengan tingkat COD limbah mula-mula. COD limbah tahu industri tahu mula-mula sebesar $3.491 \mathrm{mg} / \mathrm{L}$, apabila dilakukan pengolahan limbah dengan proses koagulasi-flokulasi menggunakan dosis koagulan serbuk biji kelor sebesar 3000 mg/L mampu menurunkan COD menjadi $1062 \mathrm{mh} / \mathrm{L}$ atau sebesar 69,58 \%. Nurhasmawaty Pohan (2008) dengan menggunakan biofilter aerobik dengan media batu kerikil sebagai biofilter untuk mengolah limbah cair industry tahu dengan variasi kombinasi $500 \mathrm{mg} / \mathrm{L}$ dalam waktu 9 jam memberikan persen reduksi COD sebesar 72,93 \% dan MLSS sebesar 74,94 \% [9]. Hasil yang diperoleh di atas 69,58 \%, jauh dari mutu limbah cair yang telah ditetapkan kep-51/MENLH/10/1995, dimana baku mutu limbah cair dapat dibuang ke lingkungan adalah $100 \mathrm{mg} / \mathrm{L}$ [2].

COD adalah banyaknya oksigen yang dibutuhkan untuk mengoksidasi secara kimia bahan organik di dalam air. COD yang diperoleh dari proses koagulasi tidak dapat memenuhi baku mutu dikarenakan banyaknya kandungan zat-zat organik dan anorganik yang terkandung didalam limbah cair industri tahu tersebut. Untuk dapat menyisihkan kadar COD yang tinggi pada limbah cair, diperlukan pengolahan lebih lanjut dari limbah cair, dalam hal ini limbah cair industri tahu. Didalam proses pengolahan limbah cair koagulasi merupakan bagian dari primary treatment (pengolahan tahap pertama) yang memiliki tujuan untuk menghilangkan padatan tersuspensi didalam air limbah. Sedangkan tahapan selanjutnya yaitu secondary treatment (pengolahan tahap kedua) bertujuan menghilangkan material organik pada limbah. Tahap ini dapat memberikan angka penyisihan COD yang lebih besar, dengan hasil yang dicapai dapat disesuaikan dengan baku mutu COD yang telah ditetapkan kep51/MENLH/10/1995, sehingga aman untuk lingkungan.

\section{Kesimpulan}

Berdasarkan hasil penelitian pemanfaatan biji kelor sebagai koagulan pada proses koagulasi limbah cair industri tahu, dapat ditarik kesimpulan sebagai berikut : waktu pengendapan optimum pada peralatan jar tes adalah 50 menit dengan penyisihan turbiditas $89,42 \%$, TSS $98,73 \%$, dan COD 69,58 \% pada dosis koagulan $3000 \mathrm{mg} / \mathrm{L}$, pH 4 limbah cair industri tahu dan ukuran partikel koagulan 50 mesh. Biji kelor merupakan koagulan yang efektif untuk limbah cair tahu, ini terlihat dari perubahan maksimal yang didapatkan melebihi $50 \%$.

\section{Daftar Pustaka}

[1] Adieska, Penelitian koagulan biji kelor pada limbah cair industri, laporan penelitian biji kelor pada limbah cair industri, http://adieska.net, diakses 25 April 2013. 
[2] Aimyaya, Tahapan Pengolahan Limbah Cair, http://aimyaya.blogspot.com, diakses 25 April 2013.

[3] Departemen Perindustrian, Direktorat Jenderal Industri Kecil Menengah, Pengolahan Limbah Cair Pangan, Jakarta, 2007.

[4] Difi, Lutfi dan Irawan, Pemanfaatan Biji Asam Jawa (Tamarindus indica) sebagai koagulan alternatif dalam proses penjernihan limbah cair industri tahu, Laporan penelitian, Departemen Teknik Kimia, Universitas Sumatera Utara, Medan, 2010.

[5] Enrico, Bernard, Pemanfaatan Biji Asam Jawa (Tamarindus indica) sebagai koagulan alternatif dalam proses penjernihan limbah cair industri tahu, Thesis program Pasca Sarjana, Universitas Sumatera Utara, Medan, 2008.

[6] Husin, A, Pengolahan Limbah Cair Industri Tahu Menggunakan Biji Kelor (Moringa oleifera Seeds) Sebagai Koagulan, Laporan Penelitian Dosen Muda, Fakultas Teknik USU, 2003.

[7] Kiely, G. Environment Engineering, Irwin McGraw-Hill, Boston, 1997.

[8] Nurhidayat, Biji Kelor Moringa Oleifera (moringa seeds), http://nurhidayat.lecture. ub.ac.id/2010/01/ Biji Kelor moringa oleifera, diakses 28 Agustus 2008.

[9] Pohan, Nurhasmawaty, Pengolahan limbah cair industri tahu dengan proses biofilter aerobik, Thesis program Pasca Sarjana, Universitas Sumatera Utara, Medan, 2008.

[10]Wiley, J. \& Sons, Principles of Industrial Waste Treatment. John Wiley \& Sons, Inc. New York, 1955. 